Hal. 62 - 75

\title{
PENGARUH VIRAL MARKETING, CELEBRITY ENDORSER DAN BRAND IMAGE TERHADAP KEPUTUSAN PEMBELIAN DI DISTRO RMBL
}

\author{
Okta Dwi Kristanto \\ Jurusan Manajemen, Fakultas Ekonomi dan Bisnis, Universitas Jember \\ oktadwikristanto@gmail.com \\ Ketut Indraningrat \\ Jurusan Manajemen, Fakultas Ekonomi dan Bisnis, Universitas Jember \\ Susanti Prasetiyaningtiyas \\ Jurusan Manajemen, Fakultas Ekonomi dan Bisnis, Universitas Jember
}

\begin{abstract}
Generally the purpose of this study was to determine the influence of viral marketing, celebrity endorser and brand image against consumer buying decisions in Distro RMBL. The population in this research was the whole followers of Distro RMBL's instagram account and the total sample of this research was 110 respondents. The independent variables were viral marketing, celebrity endorser and brand image whereas the dependent variable in this research was consumer buying decisions and this research measured by using multiple linear regression analysis. This research's result indicated that viral marketing, celebrity endorser and brand image influent positively and significantly to consumer buying decisions simultantly. Partially, viral marketing influent consumer buying decisions positively and significantly, celebrity endorser influent consumer buying decisions positively and significantly and also brand image influent consumer buying decisions positively and significantly.
\end{abstract}

Keywords: Viral Marketing, Celebrity Endorser and Brand Image

\begin{abstract}
Abstrak: Secara umum, tujuan dari penelitian ini adalah untuk menentukan pengaruh viral marketing, celebrity endorser dan brand image terhadap keputusan pembelian di distro RMBL. Populasi dalam penelitian ini adalah seluruh followers akun instagram distro RMBL yang berjumlah 107.000 orang (per bulan Desember 2015 pada saat penelitian dilakukan) dan jumlah sampel pada penelitian sejumlah 110 responden. Variabel bebas terdiri dari viral marketing, celebrity endorser dan brand image sedangkan variabel terikat dalam penelitian ini adalah keputusan pembelian yang diukur menggunakan analisis regresi linier berganda. Hasil penelitian ini menunjukkan bahwa viral marketing, celebrity endorser dan brand image berpengaruh positif dan signifikan terhadap keputusan pembelian secara simultan. Secara parsial, viral marketing berpengaruh positif dan signifikan terhadap keputusan pembelian, celebrity endorser berpengaruh positif dan signifikan terhadap keputusan pembelian dan brand image berpengaruh positif dan signifikan terhadap keputusan pembelian.
\end{abstract}

Kata Kunci: Viral Marketing, Celebrity Endorser dan Brand Image 


\section{Pendahuluan}

Pemasaran saat ini menjadi semakin horizontal karena merebaknya internet, terutama dengan hadirnya berbagai jejaring sosial, yang menjadikan segalanya menjadi sama. Perusahaan dan pelanggan tidak lagi memiliki hubungan yang bersifat vertikal, perusahaan memanfaatkan internet untuk berinteraksi secara langsung dengan pelanggan tanpa dibatasi ruang dan waktu. Sehingga saat ini pemasaran internet menjadi salah satu media yang digunakan perusahaan untuk mengenalkan berbagai macam produk dan mendekatkan diri dengan pelanggan. Tingginya jumlah netizen (orang yang mengakses dan menggunakan internet) yang menggunakan sosial media berimbas pada aktivitas pembelian. Dengan kemudahan akses internet menyebabkan perilaku konsumen berubah, konsumen cenderung untuk mencari kemudahan dalam membeli suatu produk dengan menggunakan internet.

Kemudahan tersebut dimanfaatkan sebagai salah satu metode promosi yaitu viral marketing yang merupakan promosi dari mulut ke mulut dalam format elektronik. Pemasaran viral mulai banyak diadaptasi oleh bisnis berjualan yang berbasis internet yakni online shop yang menjamur saat ini. Online shop ini mengandalkan ide-ide kreatif yang dibutuhkan agar produknya bisa dikenal dan dibeli oleh para pelanggannya. Salah satunya dengan cara endorsement, yaitu sebuah cara promosi dengan memberi pernyataan secara testimoni dengan mempromosikan atau mengiklankan produknya. Alurnya para pebisnis online shop ini akan meng-endorse para public figure yang didominasi oleh artis dengan memberikan barang dagangannya secara cuma-cuma kemudian artis yang ditunjuk itu akan membagikan foto/video untuk mempromosikan atau mengiklankan produk tersebut lewat akun pribadinya di sosial media serta memberi tanda mention pada akun online shop tersebut. Penggunaan bintang iklan dalam sebuah promosi disebut juga celebrity endorser, dimana melalui celebrity endorser pemasar dapat melakukan pembeda dengan produk-produk kompetitor yang ada di pasar. Endorser sering juga disebut direct source (sumber langsung) yaitu seorang pembicara yang mengantarkan sebuah pesan atau memperagakan sebuah produk atau jasa (Belch dan Belch, 2004:168). Keberhasilan sebuah promosi tidak terlepas dari peran bintang iklan 
dalam mempromosikan sebuah merek produk sehingga penggunaan bintang iklan dalam sebuah media merupakan alternatif strategi yang tepat untuk memperkenalkan produk kepada konsumen. Di dalam bisnis online, disinilah letak para pebisnis online shop diuntungkan, pengikut si artis akan aware dengan akun online shop-nya. Alasan mengapa harus artis/tokoh terkenal yang digunakan sebagai endorsement karena mereka dinilai populer dan memiliki pengaruh terhadap awareness followers-nya. Hal ini secara tidak langsung akan menimbulkan asosiasi produk yang dibawa endorser tersebut di dalam benak followers yang mengikuti akun media sosial pribadi milik public figure tersebut. Sebuah promosi yang baik untuk perusahaan akan dapat membangun sebuah brand image (citra merek). Brand image sangat diperlukan agar konsumen dapat mengingat sebuah merk dari asosiasi yang diciptakan. Pemberian brand (merek) dapat menambah nilai suatu produk, namun perlu pula ditinjau keuntungannya dari pihak yang berkepentingan yaitu produsen dan konsumen. Hal ini berkaitan dengan tujuan produk memberikan pelayanan yang sebaik-baiknya dalam memenuhi kebutuhan dan keinginan konsumen.

Bermacam-macam komunikasi pemasaran tersebut diharapkan dapat memberikan feedback dari calon konsumen sehingga memutuskan untuk membeli suatu produk. Menurut Kotler (2002), keputusan pembelian adalah tindakan dari konsumen untuk mau membeli atau tidak terhadap produk. Keputusan pembelian konsumen ini sangat penting bagi sebuah perusahaan baik itu perusahaan besar atau kecil. Salah satu perushaan yang memperhatikan hal ini adalah distro RMBL. Distro RMBL adalah sebuah distro yang berada di Bali dimana banyak seniman lahir dari sana. Dahulu seniman Bali sering melukis wanita bertelanjang dada, hal ini dianggap tabu bagi warga Indonesia. Akan tetapi hal ini menjadi sebuah inspirasi bagi distro RMBL, membuat image produknya berbeda berbeda dari distro lain. Distro ini menciptakan sesuatu yang dianggap masyarakat dengan alasan-alasan mainstream, seperti ketakutan yang berlebihan akan keindahan wanita, budaya alternatif dan substansi mood altering menjadi layak untuk ditampilkan. Penjelasan di atas membuat peneliti tertarik untuk melakukan penelitian dengan judul "Pengaruh Viral Marketing, Celebrity Endorser dan Brand Image terhadap Keputusan Pembelian di Distro RMBL." 


\section{Metodologi}

Penelitian ini menggunakan pendekatan penelitian penjelasan (explanatory research) yakni kausalitas menjelaskan suatu hubungan antara variabel-variabel melalui pengujian hipotesis (Ghozali, 2005). Jenis penelitian ini dipilih mengingat tujuan yang hendak dicapai mencakup usaha-usaha untuk menjelaskan hubungan dan pengaruh yang terjadi antar kuesioner sebagai alat pengumpul data primer.

Data yang digunakan dalam penelitian ini adalah data primer bersumber dari kuesioner atau daftar pernyataan dan data sekunder. Data primer dalam penelitian ini berupa tanggapan responden tentang viral marketing, celebrity endorser dan brand image terhadap keputusan pembelian di distro RMBL dan data sekunder diperoleh dalam bentuk yang sudah jadi atau sudah dikumpulkan dan diolah oleh pihak lain. Data sekunder dalam penelitian ini berupa gambaran umum distro RMBL.

Populasi dalam penelitian ini adalah seluruh followers akun instagram Distro RMBL yang berjumlah 107.000 orang (per bulan Desember 2015 pada saat penelitian dilakukan). Bila populasi besar, dan peneliti tidak mungkin mempelajari semua yang ada pada populasi, misal karena keterbatasan dana, tenaga dan waktu, maka peneliti akan mengambil sampel dari populasi itu. Teknik yang digunakan dalam penelitian ini adalah Purposive Sampling dengan beberapa kriteria yaitu orang yang pernah melakukan pembelian secara online di akun instagram Distro RMBL dan minimal melakukan pembelian sebanyak 2 kali.

Pengumpulan data yang dilakukan dengan memberikan kuesioner secara online kepada para responden dan kemudian responden akan mengisinya sesuai dengan pendapat dan persepsi responden. Data yang didapat dari kuesioner ini adalah tentang data persepsi konsumen tentang pengaruh viral marketing, celebrity endorser, brand image dan keputusan pembelian di Distro RMBL.

Pengumpulan data yang dilakukan dengan memberikan kuesioner secara online kepada para responden dan kemudian responden akan mengisinya sesuai dengan pendapat dan persepsi responden. Data yang didapat dari kuesioner ini adalah tentang data persepsi konsumen tentang 
pengaruh viral marketing, celebrity endorser, brand image dan keputusan pembelian di Distro RMBL.

\section{Hasil dan Pembahasan}

$\underline{\text { Uji Validitas }}$

Uji siginifikansi validitas instrumen juga dilakukan dengan membandingkan nilai rhitung dengan rtabel untuk degree of freedom (df) $=\mathrm{N}-2$ dalam pretest ini jumlah sampel ( $n$ ) adalah 110 sehingga besarnya (df) adalah 108 dengan tingkat signifikansi 5\% maka diketahui nilai $r_{\text {tabel }}$ adalah 0,187. Berdasarkan tabel di atas terbukti semua indikator bisa dibuktikan kevalidannya karena semua nilai rhitung lebih besar dari rtabel.

Tabel 1: Uji Validitas

\begin{tabular}{|c|c|c|c|c|c|c|}
\hline Variabel & Indikator & Yhitung & rtabel & $\begin{array}{l}\text { Nilai } \\
\text { Rekomendasi }\end{array}$ & Sig. & Keterangan \\
\hline \multirow{3}{*}{$\begin{array}{l}\text { Viral } \\
\text { Marketing } \\
\left(\mathrm{X}_{1}\right)\end{array}$} & $X_{1.1}$ & 0,813 & 0,187 & 0,30 & 0,000 & Valid \\
\hline & $X_{1.2}$ & 0,674 & 0,187 & 0,30 & 0,000 & Valid \\
\hline & $X_{1.3}$ & 0,598 & 0,187 & 0,30 & 0,000 & Valid \\
\hline \multirow{2}{*}{$\begin{array}{l}\text { Celebrity } \\
\text { Endorser } \\
\left(\mathrm{X}_{2}\right)\end{array}$} & $\mathrm{X}_{2.1}$ & 0,801 & 0,187 & 0,30 & 0,000 & Valid \\
\hline & $X_{2.2}$ & 0,788 & 0,187 & 0,30 & 0,000 & Valid \\
\hline \multirow{3}{*}{$\begin{array}{l}\text { Brand Image } \\
\left(\mathrm{X}_{3}\right)\end{array}$} & $X_{3.1}$ & 0,756 & 0,187 & 0,30 & 0,000 & Valid \\
\hline & $X_{3.2}$ & 0,723 & 0,187 & 0,30 & 0,000 & Valid \\
\hline & $X_{3.3}$ & 0,796 & 0,187 & 0,30 & 0,000 & Valid \\
\hline \multirow{3}{*}{$\begin{array}{l}\text { Keputusan } \\
\text { Pembelian } \\
\text { (Y) }\end{array}$} & $Y_{1.1}$ & 0,810 & 0,187 & 0,30 & 0,000 & Valid \\
\hline & $Y_{1.2}$ & 0,863 & 0,187 & 0,30 & 0,000 & Valid \\
\hline & $Y_{1.3}$ & 0,859 & 0,187 & 0,30 & 0,000 & Valid \\
\hline
\end{tabular}

Sumber: Data primer, 2016

$\underline{\text { Uji Reliabilitas }}$

Pengujian ini dilakukan untuk menunjukkan sejauh mana suatu hasil pengukuran relatif konsisten. Suatu pertanyaan atau pernyatan yang baik adalah pertanyaan atau pernyataan yang jelas mudah dipahami dan memiliki interpretasi yang sama meskipun disampaikan kepada responden yang berbeda dan waktu yang berlainan. Hasil uji reabilitas dalam penelitian ini ada 11 item dan menggunakan taraf signifikan cronbach's alpha 0,60. 
Tabel 2: Uji Reliabilitas

\begin{tabular}{llll}
\hline Variabel & $\begin{array}{l}\text { Cronbach } \\
\text { Alpha }\end{array}$ & Rekomendasi & Keterangan \\
\hline Viral Marketing $\left(\mathrm{X}_{1}\right)$ & 0,771 & 0,60 & Reliabel \\
\hline Celebrity Endorser $\left(\mathrm{X}_{2}\right)$ & 0,828 & 0,60 & Reliabel \\
\hline Brand Image $\left(\mathrm{X}_{3}\right)$ & 0,806 & 0,60 & Reliabel \\
\hline $\begin{array}{l}\text { Keputusan Pembelian } \\
(\mathrm{Y})\end{array}$ & 0,844 & 0,60 & Reliabel \\
\hline
\end{tabular}

Sumber: Data primer, 2016

Berdasarkan tabel 2, hasil uji reliabilitas diatas menunjukkan bahwa data yang diperoleh bersifat reliabel karena nilai Cronbach's Alpha $>0,60$. Instrumen data penelitian memberikan nilai cronbach alpha pada variabel Viral Marketing $\left(X_{1}\right)$ sebesar 0,771, Celebrity Endorser $\left(X_{2}\right)$ sebesar 0,828, Brand Image $\left(X_{3}\right)$ sebesar 0,806 dan Keputusan Pembelian ( $Y$ ) sebesar 0,844 sehingga data yang diperoleh dapat dinyatakan reliabel atau layak dipercaya sebagai alat dalam pengumpulan data.

Uji Normalitas Data

Uji normalitas diakukan dengan tujuan untuk menguji apakah dalam sebuah model regresi, variabel independen, variabel dependen atau keduanya mempunyai distribusi normal ataukah mutlak regressi yang baik adalah distribusi data normal atau mendekati normal. Untuk mengetahui bentuk distribusi data dapat menggunakan grafik P-Plot. Pada grafik P-Plot suatu data akan berdistribusi normal dapat dideteksi dengan melihat penyebaran data (titik) pada sumbu diagonal dari grafik.

Normal P-P Plot of Regression Standardized Residual

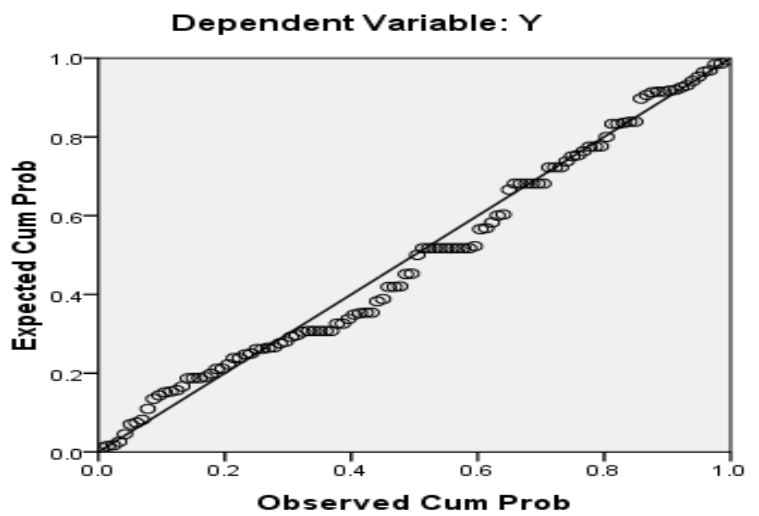

Gambar 1. Uji Normalitas

Sumber: Data Primer, 2016 
Berdasarkan hasil pengujian normalitas data dapat diketahui bahwa data menyebar dan mengikuti arah garis diagonal, sehingga pada model regresi tersebut memenuhi asumsi normalitas.

$\underline{\text { Uji Multikolinieritas }}$

Uji multikolinieritas dilakukan untuk menguji apakah model regresi yang digunakan dalam penelitian ini ditemukan adanya korelasi antar variabel independen.

Tabel 3: Uji multikolinieritas

\begin{tabular}{|c|c|c|c|c|}
\hline Variabel & VIF & Keterangan & Tolerance & Keterangan \\
\hline Viral Marketing $\left(\mathrm{X}_{1}\right)$ & 3,039 & \multirow{3}{*}{$\begin{array}{l}\text {-Kurang } \\
-10\end{array}$} & 0,329 & \multirow{3}{*}{$\begin{array}{l}\text {-Kurang } \\
-0,10\end{array}$} \\
\hline Celebrity Endorser $\left(\mathrm{X}_{2}\right)$ & 2,467 & & 0,405 & \\
\hline Brand Image $\left(\mathrm{X}_{3}\right)$ & 1,662 & & 0,602 & \\
\hline
\end{tabular}

Sumber: data primer, 2016

Berdasarkan tabel dapat diketahui bahwa tidak ada satu pun variabel yang memiliki nilai Tolerance di bawah 0,10 dan nilai Variance Inflation Factor (VIF) kurang dari 10. Maka dapat disimpulkan bahwa tidak terjadi masalah multikolinieritas pada model regresi.

\section{Uji Heteroskedastisitas}

Asumsi ini menyatakan bahwa apakah dalam model regresi terjadi ketidaksamaan varians dari residual satu dengan pengamatan yang lain. Jika varians satu residual satu pengamatan yang lain tetap, maka disebut homokesdastisitas. Dalam perhitungan melalui SPSS, dasar pengambilan keputusannya adalah:

1) Jika ada pola tertentu, titik-titik memebentuk pola (melebar, bergelombang, menyempit), maka terjadi heteroskesdastisitas.

2) Jika tidak ada pola yang jelas, titik-titik menyebar di atas dan di bawah angka 0 pada sumbu $Y$, maka tidak terjadi heteroskesdastisitas. 


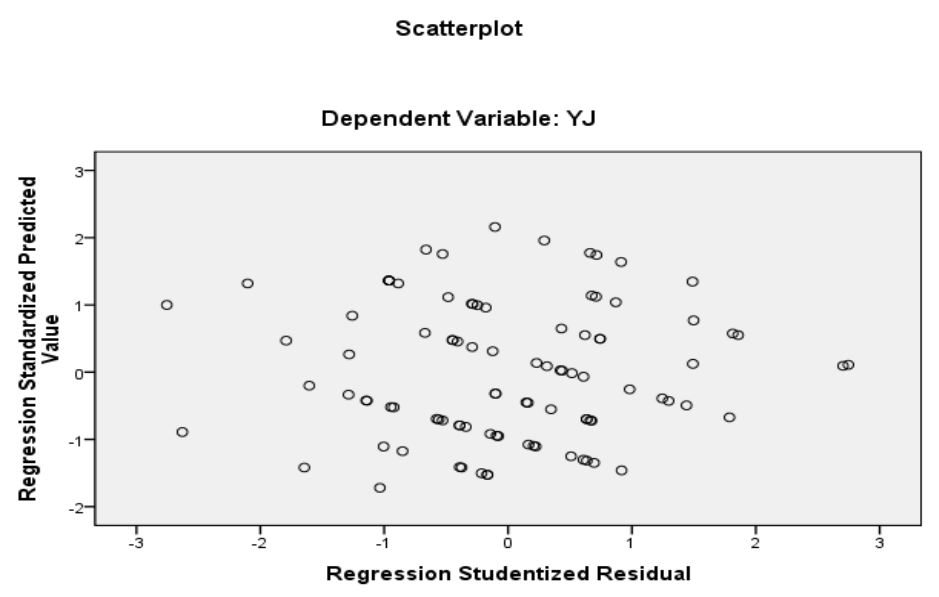

Gambar 2. Uji Heteroskesdastisitas

Sumber: Data Primer, 2016

Berdasarkan gambar hasil Uji Heteroskedastisitas dapat diketahui bahwa hasil pengujian menggambarkan tidak ada pola yang jelas, titik-titik menyebar di atas dan di bawah angka 0 pada sumbu Y. Sehingga dapat disimpulkan pada model regresi tersebut tidak terjadi gejala heteroskedastisitas.

\section{Analisis Regresi Linier Berganda}

Analisis ini bertujuan untuk mengetahui pengaruh variabel Viral Marketing, Celebrity Endorser dan Brand Image terhadap Keputusan Pembelian secara simultan dan untuk mengetahui pengaruh Viral Marketing, Celebrity Endorser serta Brand Image terhadap Keputusan Pembelian secara parsial. Proses perhitungan analisis regresi linier berganda dalam penelitian ini menggunakan software SPSS. Nilai koefisien yang ditunjukan oleh nilai output SPSS yang dinamakan Coefficient dinyatakan sebagai Standardized Coeffitient atau dikenal dengan nilai Beta. Dari hasil output regresi dengan menggunakan program SPSS, maka dapat dibentuk gambar yang menunjukkan hubungan pengaruh masing-masing variabel independent terhadap variabel dependent sebagai berikut: 


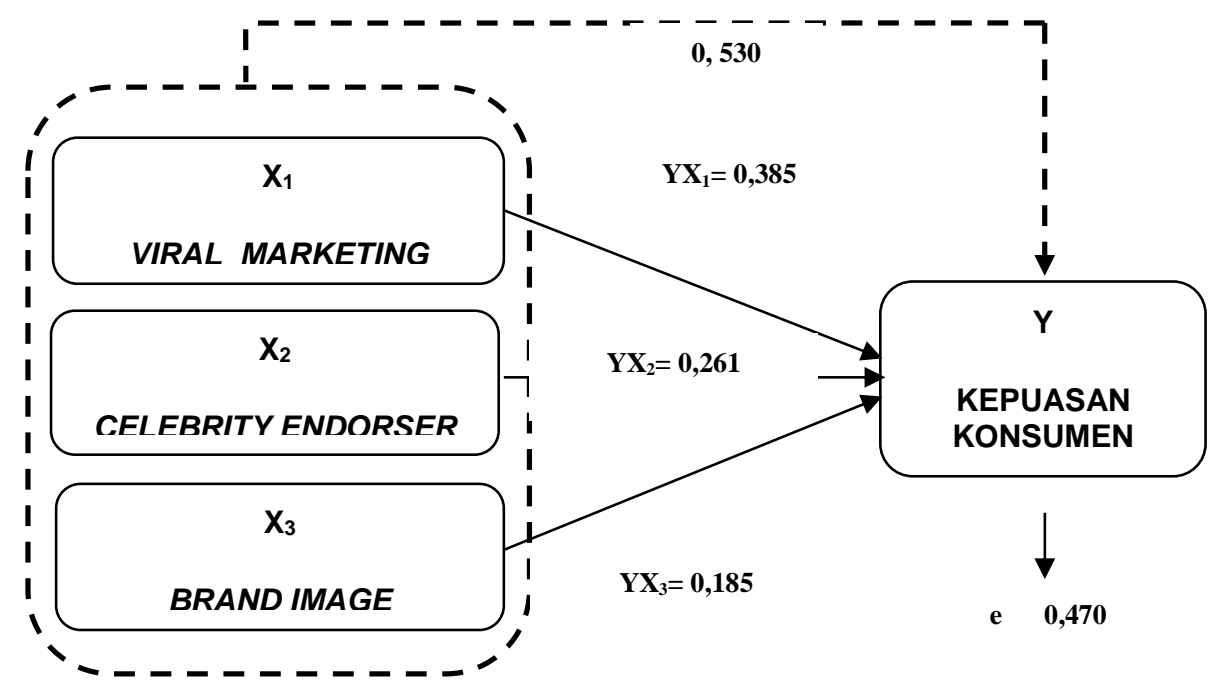

Gambar 3. Hasil Pengujian Regresi Berganda

Sumber Data : diolah

Berdasarkan gambar diatas maka dapat dibentuk persamaan regresi linier berganda sebagai berikut.

$$
Y=0,385 X_{1}+0,261 X_{2}+0,185 X_{3}+e
$$

Persamaan diatas dapat dijelaskan sebagai berikut:

1. Nilai 0,385 pada variabel viral marketing $\left(X_{1}\right)$ bernilai positif sehingga dapat dikatakan bahwa semakin tinggi program viral marketing yang dilakukan Distro RMBL, maka akan semakin meningkatkan keputusan pembelian di Distro RMBL Bali.

2. Nilai 0,261 pada variabel celebrity endorser $\left(\mathrm{X}_{2}\right)$ bernilai positif sehingga dapat dikatakan bahwa semakin tinggi program celebrity endorser yang dilakukan Distro RMBL, maka akan semakin meningkatkan keputusan pembelian di Distro RMBL Bali.

3. Nilai 0,185 pada variabel brand image $\left(\mathrm{X}_{3}\right)$ bernilai positif sehingga dapat dikatakan bahwa semakin tinggi program brand image yang dilakukan Distro RMBL, maka akan semakin meningkatkan keputusan pembelian di Distro RMBL Bali.

\section{Pengujian secara simultan (uji-F)}

Pengujian secara simultan (Uji-F) digunakan untuk menguji signikansi pengaruh secara bersama-sama antara variabel independen terhadap variabel dependen. Teknik pengujiannya dilakukan dengan cara membandingkan nilai 
Fhitung dengan nilai $F_{\text {tabel }}$ pada taraf signifikansi 0,05 dan taraf kepercayaan (level of confidence) sebesar $95 \%$.

Tabel 4. Uji F

\begin{tabular}{ccccc}
\hline Model & Df & Sig & $F_{\text {nitung }}$ & $F_{\text {tabel }}$ \\
\hline Regression & 3 & 0,000 & 41.976 & 2,69 \\
\hline Residual & 106 & & & \\
\hline Total & 109 & & & \\
\hline
\end{tabular}

Sumber: data primer, 2016

Berdasarkan hasil pengujian analisis regresi berganda pada tabel diperoleh nilai $F_{\text {hitung }}$ sebesar 41,976 dengan angka signifikansi ( $P$ value) sebesar $0,000<0,05$ dengan tingkat signifikansi $95 \%$, sedangkan pada $F_{\text {tabel }}$ sebesar 2,69. Nilai ini menunjukkan bahwa $F_{\text {hitung }}$ lebih besar daripada $F_{\text {tabel. }}$ maka Ha diterima dan Ho di tolak. Artinya variabel Viral Marketing, Celebrity Endorser dan Brand Image berpengaruh secara bersama-sama terhadap Keputusan Pembelian di Distro RMBL Bali.

Pengujian Hipotesis Secara Parsial (Uji t)

Pengujian hipotesis dilakukan dengan membandingkan nilai thitung dengan ttabel, jika nilai thitung yang dihasilkan lebih besar dari pada tabel, maka hipotesis diterima. demikian juga sebaliknya, jika nilai thitung yang dihasilkan lebih kecil dari pada tabel, maka hipotesis ditolak. Sementara itu ada tidaknya pengaruh yang signifikan dapat dilihat dari nilai signifikansi. Apabila nilai signifikansinya lebih kecil dari pada 0,05 (tingkat kepercayaan (5\%) maka variabel independen memiliki pengaruh yang signifikan terhadap variabel dependen.

Tabel 5: Hasil Uji-t

\begin{tabular}{ccccc}
\hline Variabel & Standardized Coefficients & thitung & tabel & Sig. \\
\cline { 2 - 3 } & $($ Beta $)$ & & & \\
\hline Viral Marketing & 0,385 & 3,360 & 0,001 \\
\hline Celebrity Endorser & 0,261 & 2,528 & 0,013 \\
\hline Brand Image & 0,185 & 2,181 & 0,031 \\
\hline
\end{tabular}

Sumber: data primer, 2016 
Koefisien Determinasi

Koefisien Determinasi $\left(\mathrm{R}^{2}\right)$ dilakukan untuk melihat adanya hubungan yang sempurna atau tidak, yang ditunjukkan pada apakah perubahan terhadap variabel bebas (viral marketing, celebrity endorser dan brand image) akan diikuti oleh variabel terikat (keputusan pembelian) pada proporsi yang sama. Pengujian ini dilakukan dengan melihat nilai $R$ Square $\left(R^{2}\right)$. Nilai koefisien determinasi adalah antara 0 sampai dengan 1 . Selanjutnya nilai $\left(R^{2}\right)$ yang kecil berarti kemampuan variabel-variabel independent dalam mejelaskan variasi variabel dependent amat terbatas. Nilai yang mendekati angka 1 berarti variabel-variabel independent memberikan hampir semua informasi yang dibutuhkan untuk memprediksi variasi dependent (Ghozali, 2013).

Tabel 6. Hasil Pengujian Koefisien Determinasi

\begin{tabular}{cc}
\hline & Model Summary \\
\hline Model & R Square \\
\hline 1 & 0,543 \\
\hline
\end{tabular}

Sumber: data primer, 2016

Dapat dilihat bahwa nilai $\mathrm{R}^{2}$ sebesar 0,543. Hal ini berarti bahwa variabel independen yang terdiri dari Viral Marketing, Celebrity Endorser serta Brand Image dapat menjelaskan variabel dependent dalam hal ini Keputusan Pembelian sebesar $54,3 \%$ sedangkan sisanya dipengaruhi oleh variabel lain yang tidak dimasukkan dalam penelitian ini

Pengaruh Variabel Viral Marketing $\left(\mathrm{X}_{1}\right)$, Celebrity Endorser $\left(\mathrm{X}_{2}\right)$ dan Brand Image $\left(\mathrm{X}_{3}\right)$ secara Bersama-sama terhadap Keputusan Pembelian ( $\mathrm{Y}$ ).

Hasil pengujian hipotesis dengan uji F menunjukkan bahwa variable viral marketing, celebrity endorser dan brand image secara bersama-sama berpengaruh signifikan terhadap keputusan pembelian di Distro RMBL Bali dengan nilai pengaruh sebesar 54,3\%. Hal ini berarti bahwa penerapan viral marketing, penggunaan celebrity endorser dan brand image yang diciptakan dapat meningkatkan keputusan pembelian di Distro RMBL. Berdasarkan hasil penelitian RMBL melakukan strategi viral marketing pada media instagram dirasa tepat sasaran dan pesan/ajakan yang disampaikan di dalamnya sesuai dengan trend yang berkembang di masyarakat khususnya para remaja. Selain itu faktor lain yang menjadi perhatian konsumen adalah celebrity endorser. 
Jerinx yang meng-endorse produk RMBL dirasa berhasil mempengaruhi konsumen untuk melakukan pembelian produk RMBL. Celebrity endorser RMBL cenderung mengomunikasikan pesan/ajakan yang diselipkan oleh RMBL di dalam produknya sebagai media untuk menyuarakan hal anti mainstream dan sebagai simbol perlawanan terhadap segala hal kemunafikan sesuai dengan tema RMBL. Faktor lain yang menjadi perhatian konsumen adalah brand image. Brand image atau citra merek yang baik akan suatu produk dapat membuat konsumen mudah mengingat dan tercipta asosiasi di benak konsumen sehingga dapat mempengaruhi konsumen untuk melakukan keputusan pembelian. Sehingga gabungan dari viral marketing, celebrity endorser dan brand image merupakan formulasi yang efektif dalam menyusun strategi pemasaran perusahaan untuk meningkatkan penjualan produk dan mendapat perhatian berarti dari konsumennya.

Pengaruh Viral Marketing $\left(\mathrm{X}_{1}\right)$ terhadap Keputusan Pembelian ( $\mathrm{Y}$ )

Berdasarkan teori yang dijadikan landasan teoritis dan penelitian terdahulu dalam penelitian ini, ada beberapa faktor yang berpengaruh terhadap viral marketing $\left(\mathrm{X}_{1}\right)$, yaitu messenger $\left(\mathrm{X}_{1.1}\right)$, message $\left(\mathrm{X}_{1.2}\right)$ dan environment $\left(X_{1.3}\right)$. atas dasar pemikiran tersebut, dan hasil penilaian responden pada variabel viral marketing telah menunjukkan bahwa viral marketing berpengaruh signifikan terhadap keputusan pembelian di distro RMBL Bali. Berdasarkan deskripsi variabel viral marketing dapat diketahui bahwa konsumen tertarik akan akun instagram RMBL serta konsumen tertarik untuk merekomendasikan produk yang ditawarkan di akun instagram RMBL ke orang lain dan konsumen dapat mendorong orang lain untuk membeli produk di akun instagram RMBL. Dapat dikatakan konsumen mampu menciptakan viral marketing terhadap akun instagram RMBL guna menciptakan keputusan pembelian, sehingga konsumen berasumsi bahwa strategi viral marketing yang dilakukan RMBL mempengaruhi konsumen untuk melakukan keputusan pembelian produk RMBL.

Pengaruh Celebrity Endorser $\left(\mathrm{X}_{2}\right)$ terhadap Keputusan pembelian $(\mathrm{Y})$

Beberapa faktor yang berpengaruh terhadap celebrity endorser $\left(X_{2}\right)$, yaitu attractiveness $\left(X_{2.1}\right)$ dan credibility $\left(X_{2.2}\right)$. atas dasar pemikiran tersebut, dan hasil penilaian responden pada variabel celebrity endorser telah 
menunjukkan bahwa celebrity endorser berpengaruh signifikan terhadap keputusan pembelian produk RMBL. Berdasarkan deskripsi variabel celebrity endorser dapat diketahui bahwa konsumen meyakini bahwa endorser produk RMBL memiliki daya tarik fisik dan memiliki karakter yang kuat sehingga melekat di benak mereka, konsumen meyakini endorsemproduk RMBL dapat dipercaya dan diandalkan, konsumen meyakini bahwa endorser produk RMBL dapat mewakili brand RMBL tersebut sehingga mendorong konsumen untuk melakukan pembelian. Dapat dikatakan endorser produk RMBL mampu mempengaruhi keputusan pembelian di distro RMBL.

Pengaruh Brand Image $\left(\mathrm{X}_{3}\right)$ terhadap Keputusan pembelian ( $\mathrm{Y}$ )

Beberapa faktor yang berpengaruh terhadap brand image $\left(\mathrm{X}_{3}\right)$, yaitu brand strength $\left(\mathrm{X}_{3.1}\right)$, brand favorability $\left(\mathrm{X}_{3.2}\right)$ dan brand uniqueness $\left(\mathrm{X}_{3.3}\right)$. atas dasar pemikiran tersebut, dan hasil penilaian responden pada variabel brand image telah menunjukkan bahwa brand image berpengaruh signifikan terhadap keputusan pembelian produk RMBL. Berdasarkan deskripsi variabel brand image dapat diketahui bahwa pelanggan meyakini produk yang ditawarkan RMBL berkualitas, konsumen mampu memberikan informasi kepada orang lain tentang keunggulan produk RMBL dibandingkan dengan produk lainnya di media sosial instagram dan memiliki keunikan tersendiri. Dapat dikatakan distro RMBL mampu menciptakan brand image kepada konsumennya sehingga muncul asosiasi di benak konsumen bahwa produk yang ditawarkan RMBL mampu menciptakan keputusan pembelian.

\section{Kesimpulan}

Berdasarkan hasil penelitian dan pembahasan, maka dapat ditarik beberapa kesimpulan yaitu: (1) Variabel viral marketing, celebrity endorser dan brand image secara bersama-sama berpengaruh signifikan terhadap keputusan pembelian; (2) Variabel viral marketing berpengaruh signifikan terhadap keputusan pembelian di Distro RMBL. Hal ini membuktikan bahwa penerapan viral marketing akan berpengaruh terhadap tinggi rendahnya jumlah keputusan pembelian konsumen di Distro RMBL; (3) Variabel celebrity endorser berpengaruh signifikan terhadap keputusan pembelian di Distro RMBL. Hal ini membuktikan bahwa penggunaan celebrity endorser akan berpengaruh terhadap tinggi rendahnya jumlah keputusan pembelian 
konsumen di Distro RMBL. di Distro RMBL; dan (4) Variabel brand image berpengaruh signifikan terhadap keputusan pembelian di Distro RMBL. Hal ini membuktikan bahwa brand image yang diciptakan akan berpengaruh terhadap tinggi rendahnya jumlah keputusan pembelian konsumen di Distro RMBL.

\section{Saran}

Berdasarkan hasil penelitian dan kesimpulan di atas, maka dapat dikemukakan saran antara lain: (1) menambahkan variabel lain yang juga kemungkinan memiliki pengaruh terhadap keputusan pembelian; dan (2) Diharapkan hasil penelitian ini dapat menjadi bahan evaluasi dalam menentukan strategi penjualan pada Distro RMBL.

\section{Daftar Referensi}

Belch, GeorgeE \& Belch, Michael A. 2004 : 168. Advertising and Promotion : An Integrated Marketing Communication Perspective. New York : Mc graw Hill Companies

Kotler, Philip. 2002. Manajemen Pemasaran. Edisi Milenium. Jilid Kedua. Jakarta: Prenhallindo

Ghozali, Imam. 2005. Aplikasi Analisis Multivariate dengan program SPSS. Semarang: Penerbit Universitas Diponegoro 